\title{
Mikronevrografi og forskning på perifer nevropatisk smerte
}

\begin{abstract}
BAKGRUNN Mikronevrografi er en nevrofysiologisk teknikk som muliggjør registrering fra perifere enkeltnervefibre hos våkne personer. Metoden brukes kun i forskning. Vi omtaler hvordan man ved bruk av mikronevrografi har kartlagt funksjoner i smertefibrene under normale omstendigheter og ved kroniske smertetilstander.
\end{abstract}

KUNNSKAPSGRUNNLAG Artikkelen er basert på et litteratursøk i PubMed og på forfatternes egen kjennskap til og erfaring med metoden fra forskning.

RESULTATER Mikronevrografi har bidratt til kartlegging av smerte under fysiologiske forhold og ved kroniske smertetilstander, spesielt perifer nevropatisk smerte. Man har bl.a. påvist tegn til hypereksitablitet i perifere smertefibre ved nevropatier og perifere nevropatiske smertetilstander og at andelen av hypereksitable smertefibre er større hos nevropatipasienter med kronisk smerte enn dem uten smerte. Funn tyder på at såkalte CMi-nociseptorer spiller en viktig rolle ved kronisk nevropatisk smerte.

FORTOLKNING På sikt håper vi forskning ved hjelp av mikronevrografi vil bidra til å avdekke mekanismer av direkte betydning for utvikling av målrettet behandling for nevropatisk smerte.

Ved konvensjonell nevrografi, som brukes i klinisk praksis, måles funksjonen til hele perifere nerver. Denne rutineundersøkelsen beskriver kun funksjonen til de raskeste, tykke myeliniserte fibrene, men gir ingen informasjon om tynne nervefibre $(\mathrm{A} \delta$-fibre og C-fibre). Majoriteten av nervefibrene i kroppen er umyelinsierte tynne C-fibre. Disse fibrene har mange undergrupper: To hovedgrupper er de efferente nervefibrene som tilhører det autonome nervesystemet og de afferente nervefibrene som medierer temperatur, kløe og smerte (fig 1). Ulike typer smertefibre beskrives nedenfor. I tillegg finnes det lavterskel mekanoresponsive C-fibre som man antar har en rolle $\mathrm{i}$ behagelige aspekter av berøring (1).

Ved mikronevrografi kan man registrere fra og karakterisere enkeltnervefibre, inkludert fra disse tynne nervefibrene. Dette er ikke mulig ved de testene som brukes i klinisk praksis for å kartlegge tynnfibrene, som hudbiopsier og termotest. Metoden er komplisert, tid- og ressurskrevende. Den er kun brukt i forskning og har gitt viktig kunnskap innenfor tre hovedområder: muskelspoler (2), sympatikusaktivitet (3) og tynne umyeliniserte afferente nervefibre med spesiell vekt på berøring og smerte. Innenfor disse områdene har man kartlagt normal funksjon, men også brukt dyremodeller for å se på mulige mekanismer ved patologi (3).

Vårt fokus innenfor forskning er perifere mekanismer for nevropatisk smerte. Denne artikkelen vil derfor hovedsakelig omhandle hvordan man ved bruk av mikronevrografi har kartlagt smertefibrenes funksjon under normale omstendigheter, og ved kroniske smertetilstander. Nevropatisk smerte er ny- lig definert som smerte som skyldes skade eller sykdom i det somatosensoriske systemet (4).

Vi har gjort et litteratursøk i PubMed på kombinasjoner av ordene «microneurography and history», «microneurography and c-nociceptors», «microneurography and neuropathic pain» og «microneurography and itch, neuropathic pain». Utvalget av artikler er basert på forfatternes inngående kjennskap til de få miljøene som bruker denne metoden og egen erfaring innen feltet.

\section{Historikk og innføring i metoden}

Helt tilbake til 1930-årene er det gjort forsøk på dyr med registrering fra enkeltnervefibre $(5,6)$, men først i slutten av 1960-årene klarte Vallbo \& Hagbarth å registrere fra enkeltnervefibre hos våkne forsøkspersoner ved hjelp av mikronevrografi (7). Torebjörk \& Hallin oppnådde ekstracellulære registreringer fra de tynneste nervefibrene; C-fibrene (8). Mikronevrografi vil i hovedsak kunne brukes til å kartlegge prinsipielle egenskaper og endringer i nervesystemet. Fordi man kun får registrert fra et begrenset antall fibre hos få pasienter er det ikke praktisk mulig å gjøre større epidemiologiske studier eller bruke metoden til å utrede enkeltpasienter $\mathrm{i}$ klinisk praksis.

Ved mikronevrografi lokaliseres først den aktuelle perifere nerven (hyppigst $n$. peroneus) med overflatisk elektrisk stimulering på huden. Etter at nerven er lokalisert på hudoverflaten, føres en mikroelektrode (nåleelektrode) inn i den aktuelle nerven (fig 2). Man kan da registrere signaler (aksjonspo-

\section{Kunnskapsgrunnlag}

\section{Kristin Ørstavik}

krorstav@ous-hf.no

Inge Petter Kleggetveit

Ellen Jørum

Nevrologisk avdeling

Klinisk nevrofysiologisk seksjon

Oslo Universitetssykehus, Rikshospitalet

\section{HOVEDBUDSKAP}

Mikronevrografi er en forskningsmetode der man registrerer aksjonspotensialer fra perifere enkeltnervefibre

Metoden har bidratt betydelig til å kartlegge hvordan det perifere nervesystemet koder for smerte hos friske mennesker

Det er vist endringer i egenskaper og sammensetning av smertefibre i huden hos pasienter med nevropatisk smerte

Man håper metoden vil kunne bidra til å avdekke mekanismer som har direkte betydning for utvikling av spesifikke medikamenter $\mathrm{i}$ behandlingen av pasienter med nevropatisk smerte 


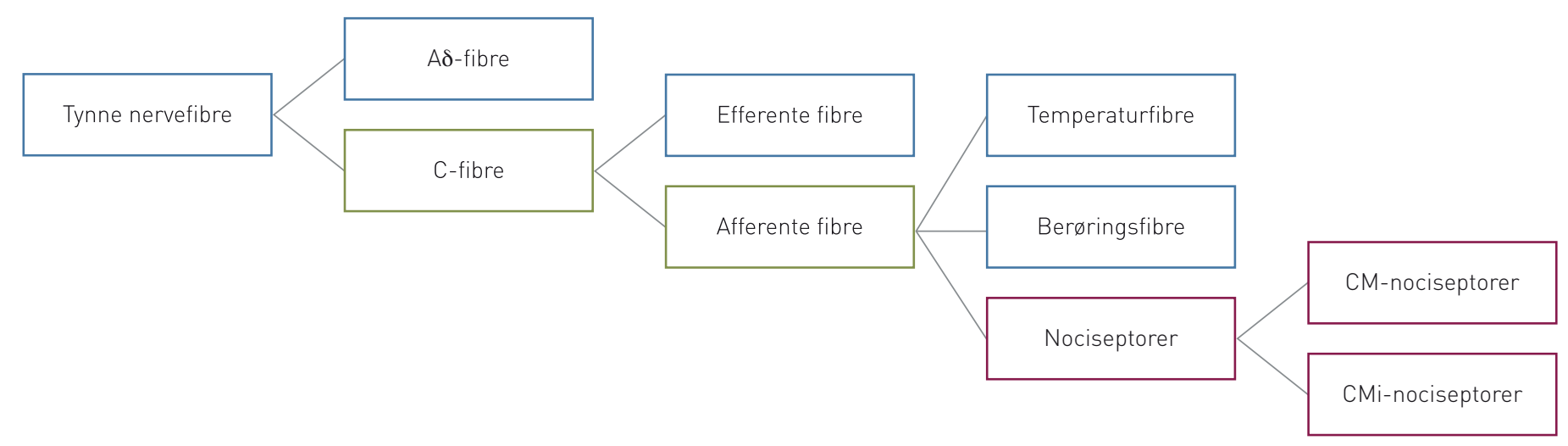

Figur 1 Skjematisk og forenklet oversikt over tynne perifere nervefibre. Afferente tynne berøringsfibre er antatt å mediere behagelige aspekter av berøring (1). C-nociseptorer inndeles $i$ to hovedgrupper og formidler ulike aspekter av smertefulle stimuli (mekanisk, termale, kjemiske) og kløe

tensialer) ekstracellulært fra nervefibre med terminaler i det aktuelle innervasjonsområdet. Innen smerteforskning er målet å få registrert fra enkeltnervefibre med reseptive felt $i$ huden.

\section{C-nociseptorer}

Det finnes ulike typer C-nociseptorer (C-fibre som formidler smerte) (9). De hyppigst forekommende er de såkalte polymodale $C$-fibrene (CM-nociseptorer eller $\mathrm{C}$-mekanoresponsive nociseptorer) som reagerer på mekaniske stimuli og oftest på varmestimuli (fig 1). Det er disse nociseptorene som har vært mest studert innen smerteforskning. De utgjør ca. $80 \%$ av smertefibrene og er blitt antatt å være ansvarlige for den akutte, normale smerten. De senere årene har man imidlertid kartlagt en annen gruppe C-nociseptorer som ikke reagerer på mekaniske stimuli (CMi-nociseptorer, C-mekanoinsensitive fibre eller såkalt «sleeping nociceptors») (9). Siden disse nervefibrene under normale omstendigheter ikke reagerer på mekaniske stimuli, har det vært vanskelig å påvise dem. De ble først beskrevet hos dyr (10). Ved en endring av mikronevrografimetoden med bruk av søking etter C-nociseptorer med elektriske impulser i huden i stedet for mekaniske stimuli, ble de også påvist hos friske forsøkspersoner (9). Aksjonspotensialene til de polymodale C-fibrene forsinkes i moderat grad når man øker frekvensen på den elektriske stimuleringen, mens dette vil være mye mer uttalt for CMi-nociseptorene $(11,12)$. Slike forskjeller avspeiler ulike membranegenskaper hos de to hovedgruppene $\mathrm{C}$-nociseptorer.

CMi-nociseptorene skiller seg fra polymodale C-nociseptorer på en rekke områder. Eksperimentelle studier har blant annet vist at det er CMi-nociseptorer som koder for smerte ved vedvarende og gjentatt hardt trykk (13) og ved injeksjon av en rekke smertefulle substanser, blant annet capsaicin (14). De er hos mennesker ansvarlige for nevrogen innflammasjon via frigjøring av vasodilatoriske nevropeptider (15). De er også blitt knyttet til mekanisk hyperalgesi (overfølsomhet for mekanisk smertefulle stimuli) og induksjon av sentral sensitisering (16). Ruehle og medforfattere viste forskjeller i cerebrale projeksjoner mellom de to hovedgruppene C-nociseptorer (17).

Tradisjonelt har man antatt at kulde medieres via $A \delta$-fibre, men mikronevrografistudier har vist at også C-fibre er involvert $\mathrm{i}$ dette (18). I tillegg er det vist at en undergruppe av CMi-nociseptorer medierer histaminutløst kløe (19), mens polymodale C-nociseptorer medierer ikke-histaminutløst kløe utløst av belgfrukten mucuna pruriens (20).

\section{Perifer nevropatisk smerte}

Nevropatisk smerte forekommer hyppig, men er vanskelig å behandle. Nevropatisk smerte som skyldes skade eller sykdom i det perifere nervesystemet inntreffer ved en rekke vanlige tilstander som diabetesnevropatier, nevropatier etter cytostatikabehandling og $\mathrm{i}$ forbindelse med nerveskader. Omfattende forskning pågår for å avdekke mekanismer for utvikling og opprettholdelse av denne typen smerte, både med tanke på å forebygge, men ikke minst for å finne frem til ny og bedre behandling. Et helt vesentlig, men vanskelig punkt er å skille ut de viktigste mekanismene for smerte, siden mange pasienter som utvikler polynevropatier eller får nerveskader ikke får nevropatiske smerter, men like fullt har patologiske forandringer.

Det er blitt hevdet at endringer i eksitabilitet i perifere nociseptorer er den viktigste enkeltfaktoren for kronisk perifer nevropatisk smerte hos mennesker (21). Mye av kunnskapen om smertemekanismer baseres i stor grad på forskning på dyremodeller. Dyremodellene er betydelig bedret de siste årene (22), men kan ikke fullt ut avspeile kompleksiteten i nevropatiske smertetilstander hos mennesker. Imidlertid har man de siste årene gjort flere mikronevrografistudier av pasienter med nevropatier og nevropatiske smertetilstander ved tegn til hypereksitabilitet, for eksempel spontanaktivitet (spontane aksjonspotensialer i smertefibre uten ytre stimuli) og sensitisering for mekaniske stimuli (nedsatt terskel for å reagere på meka- niske stimuli), i perifere C-nociseptorer (23-27). Andelen av hypereksitable C-nociseptorer er større hos nevropatipasienter med kronisk smerte sammenliknet med nevropatipasienter uten smerte (28). En viktig observasjon fra mikronevrografistudier er at tegn til hypereksitabilitet i større grad finnes i CMi-nociseptorer enn i CM-nociseptorer $(23,28)$. Dette støtter antakelsen om CMinociseptorers betydning for kronisk smerte. Det er også beskrevet andre fenomener i Cnociseptorer hos pasienter med nevropati og nevropatisk smerte, for eksempel «multiple spikes». Dette vil si at man fra et akson registrerer to eller flere aksjonspotensialer (versus normalt ett) som respons på én enkelt elektrisk stimulus. Dette tolkes som et uttrykk for hypereksitabilitet som medfører en perifer «forsterkning» og dermed flere impulser til sentralnervesystemet, noe som igjen kan føre til økt smerte (29-31). Eksitabilitet i C-nociseptorer kan i en viss grad moduleres lokalt i huden. Man har for eksempel registrert tilfeller av hemming av hypereksitabilitet (mindre spontanaktivitet, mindre multiple spikes) i C-nociseptorer når man forsiktig kjøler ned huden i tilknytning til innervasjonsområdet $(28,31)$. Dette er klinisk interessant sett i lys av at enkelte pasienter med nevropatisk smerte også ut ifra vår kliniske erfaring får lindring av sine smerter ved å kjøle ned det smertefulle området (23).

Man har i mikronevrografistudier registrert polymodale C-nociseptorer som har mistet sine naturlige sensoriske egenskaper, men fremdeles lar seg aktivere med elektriske stimuli. Dette er tolket som et uttrykk for degenerasjon av nervefibre og er blant annet sett hos pasienter med diabetesnevropati (25). I motsetning til hva man finner hos unge friske forsøkspersoner, har det hos friske eldre mennesker blitt registrert innslag av C-nociseptorer av begge kategorier med både slik «hypofunksjon» (tap av sensoriske egenskaper) og «hyperfunksjon» (sensitisering for mekaniske stimuli og spontanaktivitet) (32). Dette kan reflektere at C-fibre hos eldre er mer sårbare for påvirkning. 

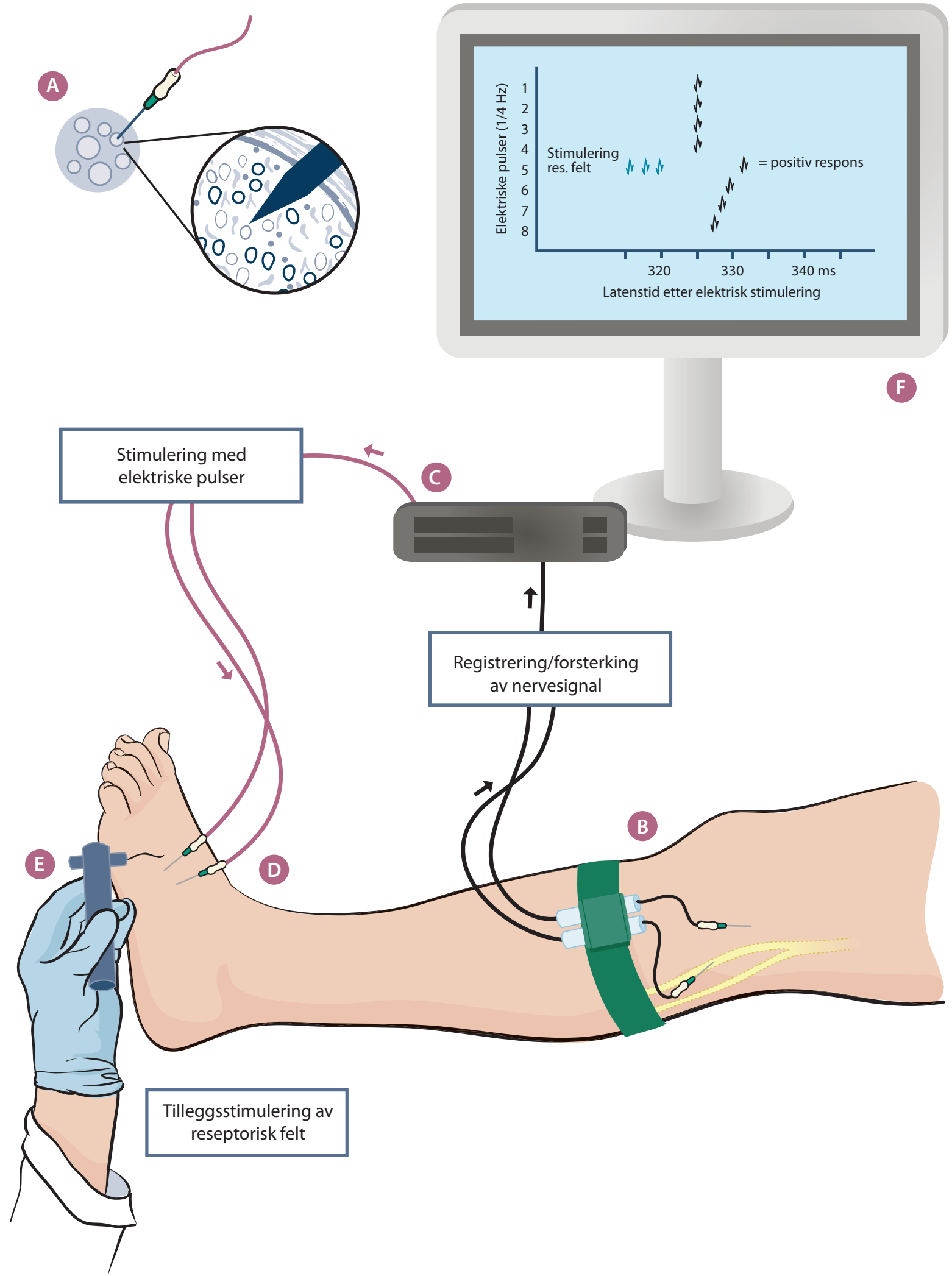

Figur 2 Mikronevrografi: al Det settes en nåleelektrode inn i en fasikkel i perifer nerve (her nervus peroneus). b) Nåleelektroden fungerer som mottaker av nervesignaler (ekstracellulær registrering av aksjonspotensialer). Impulsene gjennomgår deretter en kraftig forsterkning. c) Registreringene bearbeides og følges ved hjelp av spesiell programvare online, men lagres og analyseres offline. d) Via en stimulator som styres fra programvaren i (c) gis svake strømpulser som med en viss frekvens stimulerer C-fibre i huden. Disse nervefibrene danner da aksjonspotenisaler som igjen blir registrert i nåleelektroden (b). e) For å karakterisere C-fibrene nærmere kan man i det reseptoriske feltet gi relevante tilleggsstimuleringer (termale, kjemiske, elektriske eller som illustrert her; mekanisk stimulering ved hjelp av von Frey-filament). f) Aksjonspotensialer fra en C-nociseptor registreres på samme latenstid (se respons på elektriske pulser 1-4) etter hver elektriske stimulering (her 1/4 Hz). C-fibre har en lang latenstid grunnet lave ledningshastigheter (vanligst under $1 \mathrm{~m} / \mathrm{sek}$ ). Ved tilleggsstimulering i det reseptoriske feltet (her mekanisk stimulering med et $750 \mathrm{mN}$ von Frey-filament), vil en mekanoresponsiv C-nociseptor reagere på dette ved å fyre ekstra aksjonspotensialer (blå aksjonspotensialer). Denne ekstraaktiviteten vil føre til en lavere ledningshastighet i ettertid («activity dependent slowing of conduction velocity»; spesielt uttalt i C-nociseptorer). Dermed vil påfølgende aksjonspotensial (elektrisk utløst, $1 / 4 \mathrm{~Hz}$ ) få en plutselig økt latenstid. En positiv respons til tilleggsstimuleringen vil derfor ses ved et «hopp» mot høyre (se responsen til elektrisk puls 5) med påfølgende gradvis normalisering (se respons til elektriske pulser 6-8) når tilleggsstimuleringen har opphørt. Dette prinsippet kalles «marking» og benyttes i stor grad til å karakterisere C-fibre. Illustrasjon @ J. Engqvist/lllumedic 


\section{Mekanismebasert smertebehandling?}

Mikronevrografi i smerteforskning har til nå dreid seg om smertefysiologi og patofysiologi knyttet til spesifikke sykdommer. Forskningen har gitt en nødvendig basis for å forstå patologiske endringer som inntreffer hos pasienter med kronisk perifer nevropatisk smerte. Vi nærmer oss nå det tidspunkt der mikronevrografi kan benyttes til å belyse basale nevrofysiologiske mekanismer relatert til danningen av aksjonspotensialer, dvs. forhold knyttet til ionestrømmer over nervemembranen.

Som nevnt over, har man hos pasienter med nevropatier og nevropatisk smerte påvist tegn til hypereksitabilitet. Et sentralt spørsmål videre er hva bakgrunnen for denne er. Fysiologiske egenskaper som endringer i eksitabilitet etter forutgående aktivitet (33, 34), kan gi ytterligere informasjon om bakgrunnen for patologiske mønstre hos C-nociseptorer ved nevropatisk smerte.

De store fremskrittene innen genetisk smerteforskning de siste årene, åpner for nye muligheter innen translasjonsforskning ved hjelp av mikronevrografi. Blant annet har man vist at både spesifikke sjeldne smertetilstander (f.eks. erytromelalgi) (35) og mer vanlige smertetilstander (idiopatisk tynnfibernevropati) (36) kan kobles til mutasjoner $i$ et gen (SCNA9) som koder for en undergruppe av spenningsstyrte natriumkanaler (Nav 1.7). Enkeltnukleotidpolymorfismer av dette genet er også assosiert med økt risiko for flere vanlige smertetilstander (37). Slike patologiske ionekanaler kan uttrykkes ved hjelp av molekylærbiologiske metoder, og man har påvist ved elektrofysiologiske studier at aksonene blir hypereksitable (36). I tillegg til denne type in vitro-eksperimenter vil in vivo-forsøk med mikronevrografi hos pasienter med slike genmutasjoner kunne gi utfyllende informasjon om hypereksitabiliteten.

Man håper at forskningen på sikt vil kunne bidra til bedre behandling av kronisk perifer nevropatisk smerte, f.eks. ved medikamenter som målrettet hindrer hypereksitabilitet, blant annet spesifikke blokkere av undergrupper natriumkanaler som er spesielt relevante for nocisepsjon og smerte. Den første studien på dette feltet er allerede publisert (38).

\section{Kristin Ørstavik (f. 1963)}

er dr.med., spesialist i nevrologi og klinisk nevrofysiologi og overlege.

Forfatter har fylt ut ICMJE-skjemaet og oppgir følgende interessekonflikter: Hun er tidligere medlem av Eli-Lillys rådgivende panel, har mottatt foredragshonorar fra Eli-Lilly og Pfizer og reisest $\varnothing$ tte fra Pfizer. Deler av forskningen gjengitt her er blitt finansiert av fond fra AstraZeneca.

\section{Inge Petter Kleggetveit (f. 1977)}

er ph.d.-student ved Universitetet i Oslo og lege

i spesialisering i klinisk nevrofysiologi.

Forfatter har fylt ut ICMJE-skjemaet og oppgir følgende interessekonflikter: Deler av forskningen gjengitt her er blitt finansiert av fond fra AstraZeneca.

\section{Ellen Jørum (f. 1954)}

er professor, spesialist i nevrologi og klinisk nevrofysiologi og seksjonsoverlege.

Forfatter har fylt ut ICMJE-skjemaet og oppgir følgende interessekonflikter: Hun er medlem av redaksjonskomiteen til Smertefokus, i regi av Pfizer. Deler av forskningen gjengitt her er blitt finansiert av fond fra AstraZeneca.

\section{Litteratur}

1. Vallbo A, Olausson H, Wessberg J et al. A system of unmyelinated afferents for innocuous mechanoreception in the human skin. Brain Res 1993; 628: $301-4$

2. Hagbarth KE. Microneurography and applications to issues of motor control: Fifth Annual Stuart Reiner Memorial Lecture. Muscle Nerve 1993: 16: $693-705$.

3. Vallbo AB, Hagbarth KE, Wallin BG. Microneurography: how the technique developed and its role in the investigation of the sympathetic nervous system. J Appl Physiol 2004; 96: 1262-9.

4. Jensen TS, Baron R, Haanpää M et al. A new definition of neuropathic pain. Pain 2011: 152: 2204-5.

5. Zotterman Y. Touch, pain and tickling: an electrophysiological investigation on cutaneous sensory nerves. J Physiol 1939; 95: 1-28.

6. Namer B. Handwerker HO. Translational nociceptor research as guide to human pain perceptions and pathophysiology. Exp Brain Res 2009; 196 $163-72$

7. Vallbo AB, Hagbarth KE. Activity from skin mechanoreceptors recorded percutaneously in awake human subjects. Exp Neurol 1968; 21: 270-89.

8. Torebjörk HE, Hallin RG. C-fibre units recorded from human sensory nerve fascicles in situ. A pre liminary report. Acta Soc Med Ups 1970; 75: 81-4.

9. Schmidt R, Schmelz M, Forster C et al. Novel classes of responsive and unresponsive $\mathrm{C}$ nociceptors in human skin. J Neurosci 1995; 15: 333-41.

10. Meyer RA, Davis KD, Cohen RH et al. Mechanically insensitive afferents (MIAs) in cutaneous nerves of monkey. Brain Res 1991: 561: 252-61.

11. Weidner C, Schmelz M, Schmidt R et al. Functiona attributes discriminating mechano-insensitive and mechano-responsive $\mathrm{C}$ nociceptors in human skin. J Neurosci 1999: 19: 10184-90.

12. Serra J, Campero M, Ochoa J et al. Activitydependent slowing of conduction differentiates functional subtypes of $\mathrm{C}$ fibres innervating human skin. J Physiol 1999: 515: 799-811.

13. Schmidt R, Schmelz M, Torebjörk HE et al. Mechano-insensitive nociceptors encode pain evoked by tonic pressure to human skin. Neuroscience 2000; 98: 793-800.

14. Schmelz M. Schmid R. Handwerker $\mathrm{HO}$ et al. Encoding of burning pain from capsaicin-treated human skin in two categories of unmyelinated nerve fibres. Brain 2000; 123: 560-71.

15. Schmelz M, Michael K, Weidner $\mathrm{C}$ et al. Which nerve fibers mediate the axon reflex flare in human skin? Neuroreport 2000; 11: 645-8.

16. Schmelz M, Schmidt R. Microneurographic singleunit recordings to assess receptive properties of afferent human C-fibers. Neurosci Lett 2010, 470: 158-61.

17. Ruehle BS, Handwerker HO, Lennerz JK et al. Brain activation during input from mechanoinsen sitive versus polymodal C-nociceptors. J Neurosc 2006; 26: 5492-9.

18. Campero M, Serra J, Ochoa JL. C-polymodal nociceptors activated by noxious low temperature in human skin. J Physiol 1996; 497: 565-72.
19. Schmelz M, Schmidt R, Bickel A et al. Specific C-receptors for itch in human skin. J Neurosci 1997; 17: 8003-8

20. Namer B, Carr R, Johanek LM et al. Separate peripheral pathways for pruritus in man. J Neurophysiol 2008; 100: 2062-9

21. Scadding JW, Koltzenburg M. Painful peripheral neuropathies. I: McMahon SB, Koltzenburg M, red Wall and Melzack'sTextbook of Pain. 5. utg. London: Elsevier, 2006: 973-1000.

22. Mogil JS, Davis KD, Derbyshire SW. The necessity of animal models in pain research. Pain 2010; 151 $12-7$.

23. Ørstavik K, Weidner C, Schmidt R et al. Pathological C-fibres in patients with a chronic painful condition. Brain 2003; 126: 567-78

24. Ochoa JL, Campero M, Serra J et al. Hyperexcitable polymodal and insensitive nociceptors in painful human neuropathy. Muscle Nerve 2005: 32: $459-72$

25. Ørstavik K, Namer B, Schmidt R et al. Abnormal function of $\mathrm{C}$-fibers in patients with diabetic neuropathy. J Neurosci 2006; 26: 11287-94.

26. Serra J, Solà R, Quiles C et al. C-nociceptors sensitized to cold in a patient with small-fiber neuropathy and cold allodynia. Pain 2009; 147: 46-53.

27. Serra J, Solà R, Aleu J et al. Double and triple spikes in $\mathrm{C}$-nociceptors in neuropathic pain states: an additional peripheral mechanism of hyperalgesia. Pain 2011; 152: 343-53

28. Kleggetveit IP, Namer B, Schmidt R et al. High spontaneous activity of $\mathrm{C}$-nociceptors in painful polyneuropathy. Pain 2012: 153: 2040-7.

29. Weidner C, Schmidt R, Schmelz M et al. Action potential conduction in the terminal arborisation of nociceptive C-fibre afferents. J Physiol 2003; 547: 931-40.

30. Bostock H, Campero M, Serra J et al. Temperature-dependent double spikes in C-nociceptors of neuropathic pain patients. Brain 2005; 128 : $2154-63$.

31. Schmidt R, Kleggetveit IP, Namer B et al. Double spikes to single electrical stimulation correlates to spontaneous activity of nociceptors in painful neuropathy patients. Pain 2012; 153: $391-8$.

32. Namer B, Barta B, Ørstavik K et al. Microneurographic assessment of $\mathrm{C}$-fibre function in aged healthy subjects. J Physiol 2009; 587: 419-28.

33. Weidner C, Schmelz M, Schmidt R et al. Neural signal processing: the underestimated contribution of peripheral human C-fibers. J Neurosci 2002; 22: 6704-12.

34. Bostock H, Campero M, Serra J et al. Velocity recovery cycles of $\mathrm{C}$ fibres innervating human skin J Physiol 2003; 553: 649-63.

35. Yang Y, Wang Y, Li S et al. Mutations in SCN9A, encoding a sodium channel alpha subunit, in patients with primary erythermalgia. J Med Genet 2004; 41: 171-4.

36. Faber CG, Hoeijmakers JG, Ahn HS et al. Gain of function $\mathrm{Na}$ ?1.7 mutations in idiopathic small fiber neuropathy. Ann Neurol 2012; 71: 26-39.

37. Reimann F, Cox JJ, Belfer I et al. Pain perception is altered by a nucleotide polymorphism in SCN9A. Proc Natl Acad Sci U S A 2010; 107: 5148-53.

38. Goldberg YP, Price N, Namdari R et al. Treatment of Na(v)1.7-mediated pain in inherited erythromelalgia using a novel sodium channel blocker. Pain 2012; 153: 80-5.

Mottatt 27.1.2012, første revisjon innsendt 2.5. 2012, godkjent 6.12. 2012. Medisinsk redaktør Siri Lunde. 